Article

\title{
Comparative Review of Methods Supporting Decision-Making in Urban Development and Land Management
}

\author{
Magdalena Wagner *(D) and Walter Timo de Vries $(D)$ \\ TUM Department of Civil, Geo and Environmental Engineering, Technical University of Munich, \\ 80333 Munich, Germany \\ * Correspondence: m.wagner@o2.pl
}

Received: 3 July 2019; Accepted: 5 August 2019; Published: 7 August 2019

check for updates

\begin{abstract}
This paper discusses how and where technologies supporting decision-making can play, or are already playing, a role in both urban development and land management. The review analyzes and compares three types of technologies: cellular automata (CA), artificial intelligence (AI), and operational research (OR), and evaluates to which extent they can be useful when dealing with various land planning objectives and phases. CA is one of the most useful models for simulating urban growth, AI displays great potential as a solution to capture the dynamics of land change, and $\mathrm{OR}$ is useful in decision-making, for example to conduct locational analyses. The evaluation relies on a collection of relevant articles, selected on the basis of both content and actuality. The paper offers new perspectives towards innovative methods in urban planning and land management and highlights where and when which type of tool can be considered useful and valid. The existing gaps, i.e., phases or areas in spatial planning or land management where the methods have not been applied, are also discussed.
\end{abstract}

Keywords: cellular automata; artificial intelligence; operational research; land management; urban development

\section{Introduction}

In today's fast-moving world, information and communication technologies play important roles in our daily lives, both socially and professionally. Specific domains where these roles are increasingly intertwined are spatial planning and land management. The intertwining is rooted in the democratic rights, opportunities and privileges of citizens to contribute, via participatory processes, to co-constructing and co-deciding together with government authorities, supported by private firms, on the construction of new built-up areas, environmental protection areas and conservancies, the expansion of major infrastructure, and so forth. Such a consultation and co-design process can hardly be done without software aiding spatial analyses or urban design nowadays. Despite promising scientific and technological breakthroughs, planning practice still faces significant difficulties adopting the technologies, and a literature review indicates that there is an urgent need to develop new methods and improve already existing tools to support urban decision-making, especially at local levels [1-3].

The mother of computer-based tools used to support spatial consultation and decision-making processes or to facilitate inter-organizational interactions is what was originally labeled Decision Support Systems (DSS) [4]. In the case of urban planning or land management, this was rapidly re-labeled Spatial Decision Support Systems (SDSS), indicating that the systems were not just interactive, computer-based systems designed to assist the processes and underlying logics of decision-making, but were also aiming to solve semi-structured spatial problems [5]. An SDSS usually consists of a DSS and a Geographic Information 
System (GIS). In practice however, spatial decision support systems have a number of shortcomings. Many are designed based on specific ontological views of space and distinct epistemological approaches, which may not be shared by all stakeholders in a decision-making process. Most early-generation DSSs were in fact simple models used to better describe data or to simply visualize interactive systems. They were incapable of addressing specific decision problems or of helping decision-makers in making inevitable trade-offs [6]. Moreover, they would only cover just a small part of a decision process, without grasping the bigger perspective and complex nature of planning problems [7-9]. Over the years, the capabilities of DSSs have improved, and currently, one can observe an increasing uptake, reliance, and trust in DSSs in the domains of urban development and land management. However, the systems also exhibit an increasing complexity and a certain degree of in transparency for ordinary citizens. The degree to which citizens truly participate in and with DSS remains limited [10].

In view of these developments, the aim of the paper is to analyze and compare the analytical functionalities and requirements of a selected set of digital tools which support decision-making processes in urban development and land management. First of all, the specific aspects of these domains are discussed. Then, selected tools, namely cellular automata, artificial intelligence and multi-criteria decision analysis, are presented. Finally, new perspectives and approaches towards public participation, data mining and data analysis in urban planning and land management are offered.

\section{Software-Prone Features of Urban Planning and Land Management}

Without repeating the entire discourse of what constitutes spatial planning or land management, it is possible to select a number of aspects of both domains that are particularly suitable for what Moore [11] defines as automation or digitalization. The planning aspects discussed by Pan et al. [12] and Lagopoulos [13] may be relevant in this respect. According to Pan et al. [12], information technologies can support key points of urban big data development with respect to: infrastructural support, urban services, urban governance, and urban socio-economic development. As Lagopoulos [13] points out, there are several components of the planning model (first described by McLoughin in 1969), namely: decision to intervene, survey of spatial system, policy making (alternative scenarios), forecasting, modeling of spatial system, development of alternative spatial scenarios, evaluation and selection, and implementation. Although McLoughlin's systemic and comprehensive planning model has been criticized (for example for pure linearity of the process), it fair to say that most urban planners follow this model in a stricter or looser sense [13]. Given these two perspectives, an analytical framework to compare the usefulness and validity of new software tools can be created. The framework, in the form of a matrix, is presented and interpreted in the final paragraphs of this paper.

\section{Evaluation of Technical Tools}

Three families of methods were selected to be discussed in the paper, respectively: cellular automata (CA), artificial intelligence (AI), and operational research (OR), as presented in the Table 1 below. The methods chosen for this comparative review are, basically, applied to decision-making processes in urban planning or land management; therefore, several other, very interesting methods, are not in the scope of this paper. For example, blockchain technology is increasingly used to manage land registers, CityGML is used to store city 3D models, or various spatial databases are necessary for managing data representing objects defined in a geometric space; however, this research focuses just on the three selected digital tools. The reasons for choosing these technologies are: their relatively common use in R\&D (in general), decades of existence, as well as a substantial number of publications revolving around them, and their potential for being (further) used for land management and urban planning.

In order to evaluate the technical tools, we relied on a selection of relevant literature, where either the tool itself was discussed or where the tool was applied. The selection prioritized literature of the last 10 years, however, since origins of each of the tools date to decades earlier, we decided to, not only look at the contemporary applications, but also to take into account the historical roots.

The descriptions and evaluations of each of the methods follows the sequence: 
- historical settings and pioneers of the method;

- $\quad$ logic and tenets of the method;

- major application areas so far;

- prospective application areas.

Table 1. Brief characteristic of the selected methods.

\begin{tabular}{lcll}
\hline & Beginnings & \multicolumn{1}{c}{ Logic and Purpose } & $\begin{array}{l}\text { Major Application Areas with } \\
\text { Respect to Land Management }\end{array}$ \\
\hline Cellular automata (CA) & 1960s & $\begin{array}{l}\text { Cells represent certain components of a } \\
\text { settlement. Systems of cells are } \\
\text { interacting in a simple way but } \\
\text { displaying complex overall behavior. }\end{array}$ & $\begin{array}{l}\text { Simulation of land use changes and } \\
\text { urban dynamics; modeling urban } \\
\text { land expansion. }\end{array}$ \\
\hline Artificial intelligence (AI) & 1950s & $\begin{array}{l}\text { Machines mimic functions associated } \\
\text { with human mind, e.g., "learning" or } \\
\text { "problem solving". }\end{array}$ & $\begin{array}{l}\text { Simulating land use changes or urban } \\
\text { growth; classification of land-uses; } \\
\text { traffic or crime prediction. }\end{array}$ \\
\hline Operational research (OR) & 1940s, 1950s & $\begin{array}{l}\text { Applies advanced analytical methods of } \\
\text { problem solving and decision-making, } \\
\text { especially useful when dealing with } \\
\text { multiple, usually conflicting criteria. }\end{array}$ & $\begin{array}{l}\text { Determination of the land availability } \\
\text { for a particular purpose; locational } \\
\text { analyses; improvement of transition } \\
\text { rules in CA. }\end{array}$ \\
\hline
\end{tabular}

\subsection{Cellular Automata (CA)}

Interactions in space and time between humans and the environment, which determine land use changes, can be captured by computer simulation models [14]. Land use change models have played an important role in understanding the causes, mechanisms and consequences of land use dynamics [15]. Computational tools, such as cellular automata (CA), may be of substantial help to investigate dynamic processes such as urban growth or knowledge diffusion within such complex systems as urban environments [16].

The pioneers of applying the cellular automata to urban planning were Chapin and Weiss at the University of North Carolina in the early 1960s. They built a model where cells represented certain components of a settlement. Additionally, according to the adjacency relationship, cells were assigned degrees of attractiveness to neighboring cells [17]. In the next decade, the idea was further developed in by Tobler [18] and Albin [19]. According to definitions, cellular automaton consists of a regular grid of cells where each cell displays one of a finite number of states. The transformation of cells occurs in discrete time and is based on transition rules, on a current state of a cell, and the states of neighboring cells [17]. As highlighted by Wolfram [20], "cellular automata are systems of cells interacting in a simple way but displaying complex overall behavior." A typical cellular automata model consists of: set of cells, usually a raster grid of pixels covering an urban area; set of states associated with the cells (e.g., land uses); set of transition rules determining transformations of cells over time; update mechanism, in which rules are applied to the state in an iterative way; and an initial condition of the selected grid [21,22].

Development and usage of cellular automata can be seen in plenty of various scientific disciplines. In terms of land management, two institutions seem to be particularly outstanding: Bartlett School in London (with Michael Batty) and the Center for Connected Learning and Computer-Based Modeling, Northwestern University, Evanston, IL, led by Uri Wilensky. Both of these centers have developed their algorithms, computer programs, and theoretical models. One of the first and most famous software is DUEM (Dynamic Urban Evolutionary Modeling), which has been being developed in London and Michigan, mostly by Yichun Xie and Michael Batty (see: "Cities and Complexity" [23], "Modelling urban dynamics through GIS-based cellular automata" [24], "Cellular Automata and Urban Form: A Primer" [25]). DUEM works on five categories of land uses: housing, industry, commercial, vacant, and streets. These categories can occur (or, be classified) in one of three phases: initiating, mature, or declining. Each cell represents a part of a city, e.g., square $100 \mathrm{~m} \times 100 \mathrm{~m}$. The several transition rules are the basis for city transformation and urban growth and are defined by the authors; however, most of the rules can by adjusted by users [26]. Another commonly used software is NetLogo, which originated from StarLogo. In comparison to DUEM, NetLogo not only 
affords more individualized model building, but also allows for combining cellular automata with agent-based-modeling. The software offers a well-developed library of codes developed by various researchers (Uri Wilensky, Michael Batty, Martin Felsen, and others) and also provides users with a chance to write their own algorithms deciding on transition rules. A cellular automata model that has been successfully applied worldwide to simulate land use change is SLEUTH which was initially applied to the San Francisco Bay area [27]. SLEUTH, which is the acronym for Slope, Land-use, Exclusion, Urban, Transportation and Hillshading, has become one the most popular simulation models of urban growth and land use change, as its documentation and source code have been publicly available online, which allows researchers worldwide to revise and modify the model [21]. In SLEUTH, transition rules are a set of nested loops, where the outer loop executes Monte Carlo iterations and the inner loop executes the growth rules [27]. Thanks to the open nature of SLEUTH, there have been several modifications enriching this model; for example, pSLEUTH is a parallel version of SLEUTH, wherein the open source general-purpose parallel raster processing programming library (pRPL) was used to improve computational performance, especially during the calibration process [28]. Another version, namely SLEUTH-3r, has been reported to be 5 times more computationally efficient, reduces memory usage by $65 \%$, and enhances the model's ability to use economic, cultural and policy information [29]. All aforementioned models proved to be useful in forecasting urban growth or test spatial decisions [30].

Cellular automata can be also combined with other techniques, most commonly with the multi-agent systems (also called agent-based modeling), but attempts were similarly made to combine cellular automata with the Monte Carlo method or with the Markov chains. Multi-agent systems are based on "representing objects and populations at an elemental or individualistic level which reflects behaviors of those objects through space and time" [31]. This approach is reportedly presented as the urban models' future, as the main feature and advantage is to represent objects (or people) in an elementary way with the use of individualized units, so-called agents [30]. Behavior of agents can be determined by fairly traditional rules, but usually, it is based on the relations with the environment (cells) and other agents [31]. Multi-agent systems often show the emergence of more complex systems and are used to study various dynamic phenomena occurring in urban areas, e.g., migration, cooperation, transport, etc. [30]. In the beginning, the agent-based models were relatively highly aggregated and thus relatively simple; however, nowadays they have lower aggregation and greater heterogeneity (which consequently raises the question of the degree of the model generalization). Nevertheless, it seems fair to say that cellular automata and agent-based modeling offer great support in predicting the urban phenomena on various scales [26].

For instance, researched case studies in the field of cellular automata show usefulness of the method in:

- $\quad$ simulating urban dynamics (case study in China) using a gradient cellular automata model based on S-shaped curve evolution characteristics [32]; the authors highlight that "large-scale simulation models typically use only binary values to represent urbanization states without considering mixed types within a cell. They also ignore differences among the cells in terms of their temporal evolution characteristics at different urbanization stages". They offered a gradient cellular automaton for solving such problems and conclude that "simulation pattern derived from the gradient CA can better reflect the local disparity and temporal characteristics of urban dynamics" [32];

- determining linkages between educational infrastructure and shifts in the pattern of spatial allocation of land use change; the authors used cellular automata (parameterized on the Bayesian weights of evidence method) and analyzed the impact of educational infrastructure on urban land use change in a selected peri-urban area [33];

- modeling urban land expansion and land use/cover change (LUCC) [34] or modeling urban landscape evolution [35] by integrating cellular automata and Markov chains;

- simulating tourism growth; the authors used cellular automata to analyze the impact of the spatio-temporal growth of the city on tourism growth [36]; 
- simulating storm-water runoff and the flood inundation process during extreme storm events; the authors developed the urban flood inundation model based on cellular automata in order to effectively simulate water flow dynamics and to support city emergency management [37].

The literature review indicates that cellular automata is one of the most useful models for simulating urban growth owing to its "structure, simplicity, and possibility of evolution" [38]. On the other hand, there can be several limitations identified, such as weaknesses in the quantitative aspect or the inability to include the driving forces of urban growth in the simulation process; however, these can be minimized by integrating cellular automata with other quantitative models [38].

In recent years, an idea to combine cellular automata with artificial intelligence has been developed-this issue is discussed in the next subsection of this paper.

\subsection{Artificial Intelligence (AI)}

Artificial intelligence (AI), including machine learning (ML) and neural networks (NN), has been explored in several scientific fields and it has recently gained popularity also as a potential solution to capture dynamics of land change; nevertheless, its application within planning is still not common. So far, it has proven to be useful in certain contexts (such as traffic or crime prediction); therefore, it seems to be worth investigating as a potential remedy also for other aspects of urban planning processes and policy-making. In the review on "Artificial Intelligence Solutions for Urban Land Dynamics", Elisabete Silva and Ning Wu point out that "Artificial intelligence systems are widely accepted as a technology offering an alternative way to tackle complex and dynamic problems in urban studies" [39]. The classification of AI approaches in urban studies provided by Silva and Wu has been done in accordance with their application and properties, and has allowed for distinguishing four classes: (1) artificial life, (2) intelligent stochastic simulation models, (3) evolutionary computing and spatial DNA, and (4) knowledge-based intelligent systems [39]. The beginning of using artificial intelligence in spatial analyses dates to the 1970s [40,41]. Since artificial intelligence is based on the imitation of human intelligence by a machine, it can be useful in reasoning, planning, or problem solving. Machine learning (ML), which is a subset of artificial intelligence, is a "discipline concerned with the implementation of computer software that can learn autonomously. Expert systems and data mining programs are the most common applications for improving algorithms through the use of machine learning" [42]. One of the most common models (approaches) used within machine learning are artificial neural networks, which are "simplified models of the neurological structure of the brain" [43] and their main objective is to perform cognitive functions such as problem solving or-commercially—-to make investment decisions, recognize speech or handwriting, detect certain features or cluster data [44]. They are perceived as "a computational mechanism that is able to acquire, represent, and compute a mapping from one multivariate space of information to another, given a set of data representing that mapping" [39]. The major weaknesses of artificial neural networks are its black-box and static nature [45]. Nevertheless, it seems to be a very promising method that could significantly aid urban planners and city authorities with the challenges related to policy-making. While cellular automata, as well as agent-based-modeling, have been quite commonly used among urban planners and researchers, machine learning has been frequently applied in physical geography, where it is often integrated with remotely sensed data to classify landforms [46].

Interesting recent advancements in the area of using artificial intelligence in urban planning and land management focus, among others, on:

- combining machine learning and cellular automata for simulating land use changes [47] and urban growth [48]; as mentioned in the previous subsection of this paper, the potential of integrating AI with CA has been being explored in recent years and is proving to be highly promising;

- $\quad$ integrating an ML-CA model (MachCA) with nonlinear transition rules based on least squares support vector machines (LS-SVM) to simulate urban growth [49]; with the case study of 
Shanghai Qingpu-Songjiang area in China, authors demonstrated that the spatial configurations of rural-urban patterns can be modeled with application of the MachCA for simulating urban growth;

- integrating artificial immune systems with CA for simulating land-use dynamics under planning policies [50]; authors tested their model on the case study of the Pearl River Delta in southern China and proved that their model could be useful in exploring various planning scenarios of urban development;

- traffic flow prediction [51]; according to the authors, it has been "the first time that a deep architecture model was applied using auto-encoders as building blocks to represent traffic flow features for prediction"; additionally, the proposed method for traffic flow prediction demonstrated very good performance;

- using artificial neural networks to forecast high crime risk transportation areas in urban environment [52]; the author offered a combination of spatial clustering methods and artificial neural network models in order to predict the high crime risk transportation areas, and consequently, to improve the quality of the transportation services and also to ensure public transportation safety

- integrating knowledge-based systems with artificial neural networks and fuzzy systems to automate decision-making processes in urban planning [53]; authors indicated that combining these methods for developing urban development alternatives "achieves improvements in the implementation of each respective system as well as an increase in the breadth of functionality within the application";

- using machine learning for classifying residential areas on the basis of spatial patterns detected in a database of point locations of structures [54]; the authors tested their method in seven provinces of Afghanistan and demonstrated how to accurately map land uses and distinguish residential settlement types with $78 \%$ to $90 \%$ classification accuracy;

- using machine learning for modeling complex socio-spatial processes such as gentrification [55]; the authors used the case study of London neighborhoods and showed that machine learning can be useful to "analyze existing patterns and processes of neighborhood change to identify areas likely to experience change in the future"; additionally, they stress that "qualitative case studies must be confronted with-and complemented by-predictions stemming from other, more extensive approaches";

- $\quad$ using catboats in areas of government that deal with customer service.

To sum up the aforementioned literature references, $\mathrm{AI}$ in urban planning has been used mainly for:

- $\quad$ simulation (prediction) of city growth, focusing mostly on integrating CA with neural networks in order to forecast how cities may develop spatially; it seems that using machine learning for developing transition rules for cells (based on how the city has been developing so far, which is usually determined by analyses of historical and current trends) might be a very promising approach towards urban planning and land management;

- classification of land-uses, i.e., exploration of various ways to automatize land classification based on satellite pictures (using convolutional $\mathrm{NN}$ ) and on vector data as well;

- $\quad$ specific tasks such as traffic or crime prediction, i.e., limiting the focus to very specific and narrow subfields of city functioning and management.

As Silva and Wu [39] point out, “despite the large number of AI applications in urban planning, approaches for integrating AI techniques into a framework that includes spatial and aspatial dynamics are scarce in the literature". They suggest that a possible reason for that may include the lack of an integrated framework for researchers to embed AI approaches, difficulties related to simulating complexities of urban systems, or interdisciplinary character of modeling, so "any limitations imposed by the subjects will restrict the development of modelling" [39]. However, the remarkable (and steadily growing) number of research papers on cellular automata prove their usefulness in urban planning and land management. It seems that constant development in this field may eventually provide more powerful and accurate tools for future applications. 


\subsection{Operational Research (OR) and Multi-Criteria Decision Analysis (MCDA)}

Operational research is a discipline which focuses on the application of advanced analytical methods of problem solving and decision-making. It demonstrates usefulness in providing a systematic and scientific approach to government, military, manufacturing, service [56] but also in several business applications such as supply-chain management, resource planning or quality management [57]. MCDA (multi-criteria decision analysis), also called MCDM (multi-criteria decision making), is a sub-discipline of operational research and was developed in 1960s in the business sector. It has proved to be useful when dealing with multiple, usually conflicting, criteria. Such situations we approach in everyday life, e.g., when choosing a car, we take into account price, size, fuel consumption, safety, comfort, etc. MCDA is can help to sort alternatives, to group them, or to choose the best one [58]. This development is owed to computer development, which enabled decision-makers to conduct complex analyses of multi-criteria problems, i.e., problems that are ill-defined problems (having no optimal solution) and without very large sets of alternatives [59]. The potential of using operational research (OR), in particular, multi-criteria decision analysis (MCDA), within urban planning and land management seems to be also underrated. As Ferretti and Montibeller [60] point out, "there is an increasing use of multi-criteria spatial decision support systems in recent years for dealing with problems that have a spatial distribution of consequences"; however, due to multiple challenges, they are mainly used for single-actions solutions rather than for offering comprehensive, holistic approach.

There are many methods and approaches available for solving MCDA problems which can be applied in urban planning or land management, for example to conduct locational analyses (ranking or choosing the best location for an investment). Reportedly, the most common methods are:

- Weighted sum model, also called simple additive weighting (SAW), or its extension FuzzySAW (Fuzzy Simple Additive Weighting), which can be used to build rankings in general but also to aggregate other rankings and functions;

- ELECTRE: ELimination Et Choix Traduisant la REalité (ELimination and Choice Expressing REality). Similar to the value function approach, outranking methods build a preference relation among alternatives evaluated on several criteria. The outranking relation is "a binary relation $\mathrm{S}$ on the set $\mathrm{x}$ of alternatives such that $\mathrm{xSy}$ if there are enough arguments to declare that $\mathrm{x}$ is at least as good as y while there is no essential reason to refute that statement" [61] and it is built through a series of pairwise comparisons of the alternatives [62]. ELECTRE I was the first outranking method developed in France in 1980s; however, other outranking methods are more advanced as they accept differences in the strength of the preferences as well as the possibility of the decision-maker being indifferent with respect to two alternatives [63,64];

- PROMETHEE: Preference Ranking Organization Method for Enrichment Evaluations, which is one of the most commonly used outranking methods, and its descriptive complement geometrical analysis for interactive aid which are better known as the PROMETHEE and GAIA. The main advantage of the PROMETHEE method is the clear reasoning which helps decision-makers build well-structured framework for the decision problem. Similar to some methods from the ELECTRE family, it is useful for solving complex problems with several criteria that need to be evaluated. The method could be applied, for instance to: choosing the best location for an investment or ranking action projects. The input information is relatively clear and easy to define for both decision-makers and analysts, as it is based on a preference function associated to each criterion as well as weights describing their relative importance [61,64];

- The Analytic Hierarchy Process (AHP), which combines mathematics and psychology, is used to help decision-makers in the fields of business, transportation, or education. The decision problem is decomposed into sub-problems; then, pairwise comparison of various aspects of the problem and pairwise comparison of criteria is conducted independently. The decision-makers can either provide concrete data or just use their individual and subjective judgement using, for instance, scale 0-9 developed by Thomas Saaty. These evaluations are computed to obtain 
a final solution to the decision problem. The capability to compare incommensurable elements distinguishes the AHP from other MCDA methods [65]. Conversely, as Ronen and Coman [66] noticed, the "valuable discipline of MCDM was abused by the Analytical-Hierarchy-Process (AHP)", and became a "cumbersome and time-consuming process" [64,67];

- The Analytic Network Process (ANP) is similar to the Analytic Hierarchy Process (AHP). The basic structure is an influence network of clusters and elements. The ANP method takes into account, not only that the importance of the criteria determines the importance of the alternatives as in a hierarchy, but also that the importance of the alternatives themselves determines the importance of the criteria [68];

- DRSA: Dominance-based rough set approach is an extension of rough set theory for multi-criteria decision analysis. In the first step, the decision-maker assigns alternatives to pre-defined classes and thus expresses preference information which can be formed as a set of collective decision rules (if ... , then ... ); in the next step, the set of decision rules can be used to classify more (all) alternatives [69].

There are also methods which do not support the decision-making process directly, however, they can be used to identify the core problem or analyze relations within complex systems [70]. One such method is DEMATEL (Decision Making Trial and Evaluation Laboratory) as it is used to capture the cause-effect relationships between the elements of a system and can be used both for tangible and intangible factors [71]. The method has been applied to analyze various systems and situations, such as: marketing strategies, control systems, or safety problems [72]. To evaluate the relations, impact of each analyzed factor on each of the others is expressed in a given scale, where $0,1,2,3$, and 4 are used to illustrate no influence, low influence, medium influence, high influence, and extremely high influence, respectively; then direct and indirect influences are calculated (similar to an absorbing Markov chain matrix) and the prominence and relation are obtained. DEMATEL can be used to determine the prominence and cause-effect relationships between important regional development strategy components [70]. The method seems to be useful in understanding complex systems and relations between their components.

MCDA has been successfully integrated with other methods. For example, combining multi-criteria evaluations with cellular automata demonstrates that there is a remarkable potential and advantage in mixing these approaches:

- SLEUTH and multi-criteria evaluation (MCE) application was utilized by Mahiny and Gholamalifard [73] in Gorgan, Iran, to determine the land availability for landfill and to forecast the sprawling of the town until 2050;

- Integration of cellular automata with multi regression and multi-criteria evaluation to improve the representation of CA transition rules [74]; the authors applied the analytic hierarchy process (AHP) to analyze environmental and socioeconomic factors in case study of Kirkuk (Iraq) and to obtain suitability maps which helped to determine transition rules;

- Development of CA-based spatial multi-criteria evaluation (MCE) methodology in order to conduct land suitability simulation (LSS) [75]; the developed AHP-CA-GIS model was applied to simulate an evaluation of irrigated cropland suitability in the Macintyre Brook, Queensland, Australia and proved to be useful for optimizing land allocation.

To sum up, multi-criteria decision analysis has been applied many times for solving concrete and diverse problems in urban planning and land management, and has offered substantial support to decision-making processes where the existence and types of problems are relatively undisputed. Since most of these methods have a form of convenient and approachable computer tools (also GIS-based), it seems fair to say they might become more common in the everyday work of urban planners.

\subsection{Comparison of the Usefulness of the Discussed Methods}

The paragraphs above present and discuss how, where, and when which type of tool can be considered useful and valid. Table 2 summarizes and visualizes where and how the technologies are being adopted-either fully or partially. The existing gaps, i.e., phases or areas in spatial planning or land 
management where the methods have not been applied, are also highlighted. The table shows that there is a broad spectrum of possible applications within various stages and various development areas. The table was filled based on the literature review and own experiences of the authors. The table also highlights that in certain planning areas and in certain phases there is currently actually very few or no adoption of the tools at all. This could either indicate that alternative methods might need to be developed, or that the adoption of the methods is still counterproductive or ineffective as compared to conventional methods.

Table 2. Analytical framework to compare the usefulness and validity of the discussed methods.

\begin{tabular}{|c|c|c|c|c|}
\hline $\begin{array}{l}\text { Urban Planning Objectives } \\
\text { Components of } \\
\text { McLoughin's } \\
\text { Planning Model }\end{array}$ & $\begin{array}{l}\text { Infrastructural } \\
\text { Support }\end{array}$ & Urban Services & $\begin{array}{l}\text { Urban } \\
\text { Governance }\end{array}$ & $\begin{array}{c}\text { Urban } \\
\text { Socio-Economic } \\
\text { Development }\end{array}$ \\
\hline Decision to intervene & $\begin{array}{l}\text { AI could offer } \\
\text { technical support } \\
\text { for effective big } \\
\text { data } \\
\text { management }\end{array}$ & $\begin{array}{l}\text { CA (including } \\
\text { ABM) and OR } \\
\text { could help to } \\
\text { identify problem } \\
\text { areas }\end{array}$ & $\begin{array}{l}\text { OR could offer } \\
\text { numerical } \\
\text { rationales for } \\
\text { planned } \\
\text { interventions }\end{array}$ & $\begin{array}{l}\text { CA could be used } \\
\text { to model the } \\
\text { spatial diffusion } \\
\text { of phenomena }\end{array}$ \\
\hline Survey of spatial system & & $\begin{array}{l}\text { AI and OR could } \\
\text { offer help with } \\
\text { data analysis }\end{array}$ & $\begin{array}{l}\text { AI and OR could } \\
\text { offer help with } \\
\text { data analysis }\end{array}$ & $\begin{array}{l}\text { AI and OR could } \\
\text { provide a richer } \\
\text { data collection } \\
\text { and analysis }\end{array}$ \\
\hline $\begin{array}{l}\text { Policy making and creating alternative } \\
\text { scenarios }\end{array}$ & & $\begin{array}{l}\text { OR could be used } \\
\text { to assist } \\
\text { formulation of } \\
\text { development or } \\
\text { land conversion } \\
\text { options }\end{array}$ & $\begin{array}{l}\text { AI could be used } \\
\text { to assess the } \\
\text { support for or } \\
\text { resistance against } \\
\text { development } \\
\text { options }\end{array}$ & \\
\hline Forecasting & $\begin{array}{l}\text { CA and AI } \\
\text { (especially NN) } \\
\text { could help to } \\
\text { forecast future } \\
\text { mobility } \\
\text { requirements }\end{array}$ & $\begin{array}{l}\text { CA and AI } \\
\text { (especially NN) } \\
\text { could help to } \\
\text { forecast future } \\
\text { services } \\
\text { requirements }\end{array}$ & $\begin{array}{l}\text { CA and AI } \\
\text { (especially NN) } \\
\text { could help to in } \\
\text { virtual decision } \\
\text { rooms }\end{array}$ & $\begin{array}{l}\text { CA and AI } \\
\text { (especially NN) } \\
\text { could help to } \\
\text { forecast effects of } \\
\text { growth, and } \\
\text { changes in urban } \\
\text { phenomena }\end{array}$ \\
\hline Modeling of spatial system & $\begin{array}{l}\text { CA and AI } \\
\text { (especially NN) } \\
\text { could be used in } \\
\text { data analysis or } \\
\text { urban } \\
\text { simulations }\end{array}$ & $\begin{array}{l}\text { CA and AI } \\
\text { (especially NN) } \\
\text { could be used in } \\
\text { data analysis or } \\
\text { urban } \\
\text { simulations }\end{array}$ & $\begin{array}{l}\text { CA and AI } \\
\text { (especially NN) } \\
\text { could be used in } \\
\text { data analysis or } \\
\text { urban } \\
\text { simulations }\end{array}$ & $\begin{array}{l}\text { CA and AI } \\
\text { (especially NN) } \\
\text { could be used in } \\
\text { data analysis or } \\
\text { urban } \\
\text { simulations }\end{array}$ \\
\hline Development of alternative scenarios & $\begin{array}{l}\text { CA and AI } \\
\text { (especially NN) } \\
\text { could be used in } \\
\text { data analysis or } \\
\text { urban } \\
\text { simulations }\end{array}$ & $\begin{array}{l}\text { CA and AI } \\
\text { (especially NN) } \\
\text { could be used in } \\
\text { data analysis or } \\
\text { urban } \\
\text { simulations }\end{array}$ & $\begin{array}{l}\text { CA and AI } \\
\text { (especially NN) } \\
\text { could be used in } \\
\text { data analysis or } \\
\text { urban } \\
\text { simulations in } \\
\text { decision studios }\end{array}$ & $\begin{array}{l}\text { CA and AI } \\
\text { (especially NN) } \\
\text { could be used in } \\
\text { data analysis or } \\
\text { urban } \\
\text { simulations }\end{array}$ \\
\hline Evaluation and selection of choices & $\begin{array}{l}\text { OR could be used } \\
\text { to compare } \\
\text { alternatives, } \\
\text { build rankings } \\
\text { and choose } \\
\text { preferred } \\
\text { solutions }\end{array}$ & $\begin{array}{l}\text { OR could be used } \\
\text { to compare } \\
\text { alternatives, } \\
\text { build rankings } \\
\text { and choose } \\
\text { preferred } \\
\text { solutions }\end{array}$ & $\begin{array}{l}\text { OR could be used } \\
\text { to compare } \\
\text { alternatives, } \\
\text { build rankings } \\
\text { and choose } \\
\text { preferred } \\
\text { solutions }\end{array}$ & $\begin{array}{l}\text { OR could be used } \\
\text { to compare } \\
\text { alternatives, } \\
\text { build rankings } \\
\text { and choose } \\
\text { preferred } \\
\text { solutions }\end{array}$ \\
\hline Implementation & & $\begin{array}{l}\text { CA or OR could } \\
\text { be used in } \\
\text { support of } \\
\text { enforcement }\end{array}$ & $\begin{array}{l}\text { CA or OR could } \\
\text { be used to reflect } \\
\text { on effectiveness } \\
\text { of decisions }\end{array}$ & $\begin{array}{l}\text { CA or OR could } \\
\text { be used to test } \\
\text { and evaluate } \\
\text { historical trends }\end{array}$ \\
\hline
\end{tabular}




\section{Conclusions and Discussions}

Literature review indicates that cellular automata helps mainly to forecast city growth, artificial intelligence is useful in data analysis or urban simulations, and multi-criteria decision analysis can be used for choosing best locations for an investment. The selected methods have been applied many times for solving diverse problems in urban planning and land management and proved to be useful in many situations. Since most of these methods have a form of convenient and approachable computer tools, it seems fair to say they might become more common in the everyday work of urban planners especially in designing, evaluating and solving decision problems. Nevertheless, there are still several challenges that need to be mitigated, including how to deal with the political variability of framing problems and assigning priorities, and including the increased connectedness and complexity of problems. However, the manner and direction in which the methods are evolving, combined with the increased persuasiveness and adoption of innovative technologies in the political processes [76,77], could result in increased popularity among planners and policy-makers. Reportedly, among the directions for further development, the actions could be highlighted: AI should become more approachable and understandable for ordinary citizens (also human-machine interaction is a vast topic nowadays); cellular automata need further extensions and developments (in terms of transition rules and "substance" of cells) so that it becomes more accurate and repeatable; OR constantly faces accusations of "black-box-nature" which requires more debate and also user-friendly software. Nevertheless, the aforementioned methods show high potential for urban planners and policy-makers and, as such, deserve further consideration.

Author Contributions: Conceptualization, M.W. and W.T.d.V.; Methodology, M.W.; Investigation M.W. and W.T.d.V.; Writing—original draft preparation, M.W. and W.T.d.V.; Writing—review and editing, M.W. and W.T.d.V.

Funding: This research received no external funding.

Conflicts of Interest: The authors declare no conflict of interest.

\section{References}

1. De Vries, W.T. Wandel verstehen. Haltung zeigen. Kompetenzen entwickeln. Ein Fazit der Tagung. (Understanding change. Show attitude. Develop competences. A summary of the workshop). In 18. Münchner Tage für nachhaltiges Landmanagement. Menschen kommen und Menschen gehen. Wie bleiben Kommunen im Gleichgewicht. Resiliente Ländliche Räume in Zeiten globaler und Regionaler Wanderungsbewegungen; de Vries, W.T., Ed.; Materialiensammlung Lehrstuhl für Bodenordnung und Landentwicklung, TUM: Munich, Germany, 2016; Volume 48, pp. 74-77.

2. De Toro, P.; Iodice, S. Evaluation in Urban Planning: A multi-criteria approach for the choice of alternative Operational Plans in Cava De' Tirreni. AESTIMUM 2016, 69, 93-112.

3. Angilella, S.; Bottero, M.; Corrente, S.; Ferretti, V.; Greco, S.; Lami, I.M. Non Additive Robust Ordinal Regression for urban and territorial planning, an application for siting an urban waste landfill. Ann. Oper. Res. 2016, 245, 427-456. [CrossRef]

4. Eom, S.B. Decision support systems. In International Encyclopaedia of Business and Management, 2nd ed.; Warner, M., Ed.; International Thomson Business Publishing Co.: London, UK, 2001.

5. Sprague, R.H.; Carlson, E.D. Building Effective Decision Support Systems; Prentice-Hall, Inc.: Englewood Cliffs, NJ, USA, 1982.

6. Giove, S.; Brancia, A.; Satterstrom, F.K.; Linkov, I. Decision Support Systems and Environment: Role of MCDA. In Decision Support Systems for Risk Based Management of Contaminated Sites; Marcomini, A., Suter, G.W., II, Critto, A., Eds.; Springer: New York, NY, USA, 2009.

7. Moghadam, S.T.; Delmastro, C.; Lombardi, P.; Corgnati, S. Towards a New Integrated Spatial Decision Support System in Urban Context. Procedia Soc. Behav. Sci. 2016, 223, 974-981. [CrossRef]

8. Omrani, H.; Tayyebi, A.; Pijanowski, B. Integrating the multi-label land-use concept and cellular automata with the artificial neural network-based Land Transformation Model, An integrated ML-CA-LTM modeling framework. GISci. Remote Sens. 2017, 54, 283-304. [CrossRef] 
9. Zhang, H.; Malczewski, J. Quality evaluation of volunteered geographic information. In Volunteered Geographic Information and the Future of Geospatial Data; Campelo, C.E.C., Bertolotto, M., Corcoran, P., Eds.; IGI Global: Hershey, PA, USA, 2017; pp. 19-46.

10. De Vries, W.T. Potential of big data for pro-active participatory land use planning. Geoplanning. J. Geomat. Plan. 2018, 5, 205-214. [CrossRef]

11. Moore, S. Digitalization or Automation-Is There a Difference. Gartner. 2015. Available online: https://www.gartner. com/smarterwithgartner/digitalization-or-automation-is-there-a-difference/ (accessed on 21 May 2019).

12. Pan, Y.; Tian, Y.; Liu, X.; Gu, D.; Hua, G. Urban big data and the development of city intelligence. Engineering 2016, 2, 171-178. [CrossRef]

13. Lagopoulos, A. Clarifying Theoretical and Applied Land-Use Planning Concepts. Urban Sci. $2018,2,17$. [CrossRef]

14. Veldkamp, A.; Verburg, P.H. Modeling land use change and environmental impact. J. Environ. Manag. 2004, 72, 1-3. [CrossRef]

15. Chaudhuri, G.; Clarke, K. The SLEUTH Land Use Change Model: A Review. Int. J. Environ. Resour. Res. 2013, 1, 88-104.

16. Ishida, Y. A Critical Phenomenon in a Self-repair Network by Mutual Copying. In Knowledge-Based Intelligent Information and Engineering Systems; Khosla, R., Howlett, R.J., Jain, L.C., Eds.; Lecture Notes in Computer Science; Springer: Berlin, Germany, 2005; Volume 3682, pp. 86-92.

17. Chapin, F.S.; Weiss, S.F. A Probabilistic Model for Residential Growth. Transportation 1968, 2, $375-390$. [CrossRef]

18. Tobler, W.R. A Computer Movie Simulating Urban Growth in the Detroit Region. Econ. Geogr. 1970, 46, $234-240$. [CrossRef]

19. Albin, P.S. The Analysis of Complex Socioeconomic Systems; D.C. Heath and Company: Lexington, MA, USA, 1975.

20. Wolfram, S. Theory and Application of Cellular Automata; World Scientific: Singapore, 1986.

21. Clarke, K.C. A Decade of Cellular Urban Modeling with SLEUTH, Unresolved Issues and Problems. In Planning Support Systems for Cities and Regions; Brail, R.K., Ed.; Lincoln Institute of Land Policy: Cambridge, MA, USA, 2008; pp. 47-60.

22. Berberoglu, S.; Akin, A.; Clarke, K.C. Cellular automata modeling approaches to forecast urban growth for Adana, Turkey: A comparative approach. Landsc. Urban Plan. 2016, 153, 11-27. [CrossRef]

23. Batty, M. Cities and Complexity-Understanding Cities with Cellular Automata, Agent-Based Models, and Fractals; MIT Press: Cambridge, MA, USA, 2005.

24. Batty, M.; Xie, Y.; Sun, Z. Modeling Urban Dynamics through GIS-Based Cellular Automata. Comput. Environ. Urban Syst. 1999, 23, 205-233. [CrossRef]

25. Batty, M. Cellular automata and urban form: A primer. J. Am. Plan. Assoc. 1997, 63, 266-274. [CrossRef]

26. Xie, Y. A Generalized Model for Cellular Urban Dynamics. Geogr. Anal. 1996, 28, 350-373. [CrossRef]

27. Clarke, K.C.; Gaydos, L. Loose-coupling a cellular automaton model and GIS, long-term urban growth prediction for San Francisco and Washington/Baltimore. Int. J. Geogr. Inf. Sci. 1998, 12, 699-714. [CrossRef] [PubMed]

28. Guan, Q.; Clarke, K.C. A general-purpose parallel raster processing programming library test application using a geographic cellular automata model. Int. J. Geogr. Inf. Sci. 2010, 24, 695-722. [CrossRef]

29. Jantz, C.A.; Goetz, S.J.; Donato, D.; Claggett, P. Designing and implementing a regional urban modeling system using the SLEUTH cellular urban model. Comput. Environ. Urban Syst. 2010, 34, 1-16. [CrossRef]

30. Wagner, M. Computer-based tools aiding the process of spatial planning. Urban. Inf. 2014, 257, 72-76.

31. Batty, M. Urban Modeling. In International Encyclopedia of Human Geography; Kitchin, R., Thrift, N., Eds.; Elsevier: Oxford, UK, 2009.

32. Liu, X.; Hu, G.; Ai, B.; Li, X.; Tian, G.; Chen, Y.; Li, S. Simulating urban dynamics in China using a gradient cellular automata model based on S-shaped curve evolution characteristics. Int. J. Geogr. Inf. Sci. 2018, 32, 73-101. [CrossRef]

33. Campos, P.B.R.; Almeida, C.M.; Queiroz, A.P. Educational infrastructure and its impact on urban land use change in a periurban area: A cellular-automata based approach. Land Use Policy 2018, 79, 774-788. [CrossRef] 
34. Rimal, B.; Zhang, L.; Keshtkar, H.; Haack, B.N.; Rijal, S.; Zhang, P. Land Use/Land Cover Dynamics and Modeling of Urban Land Expansion by the Integration of Cellular Automata and Markov Chain. ISPRS Int. J. Geo Inf. 2018, 7, 154. [CrossRef]

35. Nguyen, T.A.; Le, P.M.T.; Pham, T.M.; Hoang, H.T.T.; Nguyen, M.Q.; Ta, H.Q.; Hens, L. Toward a sustainable city of tomorrow: A hybrid Markov-Cellular Automata modeling for urban landscape evolution in the Hanoi city (Vietnam) during 1990-2030. Environ. Dev. Sustain. 2019, 21, 429-446. [CrossRef]

36. Lupu, C.; Peng, X.; Muntele, I. Using cellular automata to simulate tourism growth. Case study: Iaşi city. Hum. Geogr. J. Stud. Res. Hum. Geogr. 2018, 12, 115-128. [CrossRef]

37. Liu, L.; Liu, Y.; Wang, X.; Yu, D.; Liu, K.; Huang, H.; Hu, G. Developing an effective 2-D urban flood inundation model for city emergency management based on cellular automata. Nat. Hazards Earth Syst. Sci. 2015, 15, 381-391. [CrossRef]

38. Aburas, M.M.; Ho, Y.M.; Ramli, M.F.; Ash'aari, Z.H. The simulation and prediction of spatio-temporal urban growth trends using cellular automata models: A review. Int. J. Appl. Earth Obs. Geoinf. 2016, 52, 380-389. [CrossRef]

39. Wu, N.; Silva, E. Artificial Intelligence Solutions for Urban Land Dynamics: A Review. J. Plan. Lit. 2010, 24, 246-265.

40. Los, M. Spatial Design and Artificial Intelligence; University of Pennsylvania Press: Philadelphia, PA, USA, 1973.

41. Tobler, W.R. Cellular Geography. In Philosophy in Geography; Gale, S., Olsson, G., Eds.; Reidel: Dordrecht, The Netherlands, 1979; pp. 379-386.

42. Hosch, W.L. Machine Learning. Encyclopædia Britannica. 2016. Available online: https://www.britannica.com/ technology/machine-learning (accessed on 21 May 2019).

43. Thagard, P. Cognitive Science. Encyclopædia Britannica. 2013. Available online: https://www.britannica.com/ science/cognitive-science (accessed on 21 May 2019).

44. Zwass, V. Neural Network. Encyclopædia Britannica. 2018. Available online: https://www.britannica.com/ technology/neural-network (accessed on 21 May 2019).

45. Cheng, J. Modelling Spatial \& Temporal Urban Growth; Department of Geographical Sciences: Utrecht, The Netherlands, 2003.

46. Xiao, N. Machine learning. In International Encyclopedia of Geography, People, the Earth, Environment and Technology; Richardson, D., Castree, N., Goodchild, M.F., Kobayashi, A., Liu, W., Marston, R.A., Eds.; John Wiley \& Sons: Chichester, UK, 2017.

47. Charif, O.; Omrani, H.; Basse, R.M. Cellular automata based on artificial neural network for simulating land use changes. In Proceedings of the 45th Annual Simulation Symposium, Society for Computer Simulation International, Orlando, FL, USA, 26-30 March 2012.

48. Shafizadeh-Moghadam, H.; Asghari, A.; Tayyebi, A.; Taleai, M. Coupling machine learning, tree-based and statistical models with cellular automata to simulate urban growth. Comput. Environ. Urban Syst. 2017, 64, 297-308. [CrossRef]

49. Feng, Y.; Liu, Y.; Batty, M. Modeling urban growth with GIS based cellular automata and least squares SVM rules: A case study in Qingpu-Songjiang area of Shanghai, China. Stoch. Environ. Res. Risk Assess. 2016, 30, 1387. [CrossRef]

50. Liu, X.; Li, X.; Shi, X.; Zhang, X.; Chen, Y. Simulating land-use dynamics under planning policies by integrating artificial immune systems with cellular automata. Int. J. Geogr. Inf. Sci. 2010, 24, 783-802. [CrossRef]

51. Lv, Y.; Duan, Y.; Kang, W.; Li, Z.; Wang, F. Traffic Flow Prediction with Big Data: A Deep Learning Approach. IEEE Trans. Intell. Transp. Syst. 2015, 16, 865-873. [CrossRef]

52. Kouziokas, G. The application of artificial intelligence in public administration for fore-casting high crime risk transportation areas in urban environment. Transp. Res. Procedia 2017, 24, 467-473. [CrossRef]

53. Feng, S.; Xu, L.D. Hybrid artificial intelligence approach to urban planning. Expert Syst. 1999, 16, $248-261$. [CrossRef]

54. Jochem, W.; Bird, T.; Tatem, A. Identifying residential neighbourhood types from settle-ment points in a machine learning approach. Comput. Environ. Urban Syst. 2018, 69, 104-113. [CrossRef]

55. Reades, J.; De Souza, J.; Hubbard, P. Understanding urban gentrification through machine learning. Urban Stud. 2018, 56, 922-942. [CrossRef] 
56. Blumenfeld, D.E.; Elkins, D.A.; Alden, J.M. Mathematics and operations research in industry. Focus 2004, 24, 10-12.

57. Pintér, J. Operations Research. MathWorld-A Wolfram Web Resource. Eric, W. Weisstein. Available online: http://mathworld.wolfram.com/OperationsResearch.html (accessed on 21 May 2019).

58. Figueira, J.; Ehrgott, M.; Greco, S. Multiple Criteria Decision Analysis, State of the Art Surveys; Springer: Berlin, Germany, 2005.

59. Xu, D.L.; Yang, B. Introduction to Multi-Criteria Decision Making and the Evidential Reasoning Approach; Working Paper Series; Manchester School of Management: Mancheste, UK, 2001; pp. 1-21.

60. Ferretti, V.; Montibeller, G. Key challenges and meta-choices in designing and applying multi-criteria spatial decision support systems. Decis. Support Syst. 2016, 84, 41-52. [CrossRef]

61. Brans, J.P.; De Smet, Y. Promethee methods. In Multiple Criteria Decision Analysis, State of the Art Surveys, 2nd ed.; Figueira, J., Greco, S., Ehrgott, M., Eds.; Springer: Boston, MA, USA, 2016; pp. 187-220.

62. Bouyssou, D. Outranking Methods. In Encyclopedia of optimization; Floudas, C.A., Pardalos, P.M., Eds.; Kluwer Academic Publishers: Dordrecht, The Netherlands, 2001.

63. De Boer, L.; van der Wegen, L.; Telgen, J. Outranking methods in support of supplier selection. Eur. J. Purch. Supply Manag. 1998, 4, 109-118. [CrossRef]

64. Wagner, M. A research proposal on the parametric city governance. In Smart and Sustainable Planning for Cities and Regions. Results of SSPCR 2015; Bisello, A., Vettorato, D., Stephens, R., Elisei, P., Eds.; Springer International Publishing: Cham, Switzerland, 2016; pp. 205-219.

65. Saaty, T.L.; Peniwati, K. Group Decision Making: Drawing out and Reconciling Differences; RWS Publications: Pittsburgh, PA, USA, 2008.

66. Ronen, B.; Coman, A. Overdosed management: How excess of excellence begets failure. Hum. Syst. Manag. 2009, 28, 93-99.

67. Zeleny, M. Multiple Criteria Decision Making (MCDM): From paradigm lost to paradigm regained. J. Multi-Criteria Decis. Anal. 2011, 18,77-89. [CrossRef]

68. Saaty, T.L. The Analytic Network Process. Iran. J. Oper. Res. 2008, 1, 1-27.

69. Greco, S.; Matarazzo, B.; Slowiński, R. Rough sets theory for multicriteria decision analysis. Eur. J. Oper. Res. 2001, 129, 1-47. [CrossRef]

70. Wagner, M. Supporting strategy making. Towards a New Architecture of Knowledge, Big Data, Culture and Creativity. In Proceedings of the IFKAD 2016, 11th International Forum on Knowledge Asset Dynamics, Dresden, Germany, 15-17 June 2016; Spender, J.C., Schiuma, G., Noennig, J.R., Eds.; pp. 2053-2064.

71. Fontela, E.; Gabus, A. DEMATEL, Innovative Methods. Technical Report no. 2, Structural Analysis of the World Problematique; Battelle Geneva Research Institute: Geneva, Switzerland, 1974.

72. Lee, H.S.; Tzeng, G.H.; Yeih, W. Revised DEMATEL, resolving the infeasibility of DEMATEL. Appl. Math. Model. 2013, 37, 6746-6757. [CrossRef]

73. Mahiny, A.S.; Gholamalifard, M. Linking SLEUTH urban growth modeling to multi-criteria evaluation for a dynamic allocation of sites to landfill. In 2011 International Conference on Computational Science and Its Applications; Springer: Berlin/Heidelberg, Germany, 2011.

74. Omar, N.Q.; Sanusi, S.A.; Hussin, W.M.; Samat, N.; Mohammed, K.S. Markov-CA Model Using Analytical Hierarchy Process and Multi-Regression Technique. IOP Conf. Ser. Earth Environ. Sci. 2014, 20, 012008. [CrossRef]

75. Yu, J.; Chen, Y.; Wu, Y.; Khan, S. Cellular automata-based spatial multi-criteria land suitability simulation for irrigated agriculture. Int. J. Geogr. Inf. Sci. 2011, 25, 131-148. [CrossRef]

76. Helbing, D.; Frey, B.S.; Gigerenzer, G.; Hafen, E.; Hagner, M.; Hofstetter, Y.; Zwitter, A. Will Democracy Survive Big Data and Artificial Intelligence? In Towards Digital Enlightenment; Helbing, D., Ed.; Springer: Berlin, Germany, 2019; pp. 73-98.

77. Mulgan, G. Artificial intelligence and collective intelligence, the emergence of a new field. AI Soc. 2018, 33, 631-632. [CrossRef]

(C) 2019 by the authors. Licensee MDPI, Basel, Switzerland. This article is an open access article distributed under the terms and conditions of the Creative Commons Attribution (CC BY) license (http://creativecommons.org/licenses/by/4.0/). 